\title{
Partisipasi Masyarakat Sipil dalam Otonomi Daerah Menurut Undang-Undang No. 22 Tahun 1999
}

\author{
Mustari Pide
}

\begin{abstract}
The 1999 Regulation Number 22 gives a wide opportunity for the local people to participate in the government and development. To make the efforts grow, develop and well adopted the civil society existence is need to articulate them. It could articulate the people interest if it solid a support from the local government and local people.
\end{abstract}

\section{Pendahuluan}

Undang-Undang No. 22 Tahun 1999 tentang Pemerintahan Daerah memberi kesempatan yang besar dan luas pada masyarakat daerah untuk berpartisipasi dalam pemerintahan dan pembangunan di daerahnya. Masyarakat daerah secara individu sudah tentu agak sulit berpartisipasi secara langsung dalam pemerintahan dan pembangunan baik itu karena terbatasnya rata-rata kemampuan individu, atau karena kebutuhan, tuntutan dan kepentingannya sangat beragam; ataupun karena partisipasi secara sendiri-sendiri atau dengan kelompok yang kecil sering kurang didengarkan oleh lembaga pengambil keputusan di daerah.

Ada kalanya suara pemimpin-pemimpin non-formal didengar oleh para pengambil keputusan tetapi biasanya terbatas ruang lingkupnya dan sering hanya menyangkut kasuskasus tertentu. Karena itu agar kepentingan masyarakat yang beragam itu dapat tersalurkan dengan baik diperlukan "agen" dalam bentuk organisasi yang lebih teratur dan berwibawa untuk mengartikulasikan kepentingan dan kebutuhan masyarakat tadi agar dapat diperjuangkan sebagai salah satu alternatif untuk dijadikan sebagai kebijakan daerah. Alternatif tersebut bersama alternatif-alternatif lainnya dipadukan (diagregasikan) oleh partaipartai politik dan DPRD, menjadi alternatifalternatif yang lebih sedikit jumlahnya, lebih sempurna dan lebih terarah dan oleh DPRD bersama Kepala Daerah dibahas dan dipilih untuk dijadikan Peraturan Daerah atau dalam bentuk kebijakan lain. Agen tersebut biasa disebut sebagai civil society. 
Civil society sering diterjemahkan sebagai "masyarakat sipil" dan belakangan ini juga sering disebut "masyarakat madani", adalah bidang kehidupan sosial yang terorganisasi secara sukarela, mandiri dalam arti self-generating dan self supporting otonom dari pengaruh kekuasaan pemerintah dan hanya tunduk pada ketentuan peraturan perundangundangan.Civil society mencakup lembagalembaga atau kelompok-kelompok yang sangat luas baik formal ataupun non formal yang meliputi bidang-bidang kehidupan: 1) ekonomi (organisasi ekspor-impor, pertekstilan, perkumpulan koperasi, kamar dagang dsb); 2) kebudayaan (organisasi berdasarkan sukubangsa, kedaerahan, kekerabatan, kesenian dsb); 3) keagamaan; 4) pendidikan dan informasi (organisasi guru, perguruan swasta, wartawan, penerbit, pelajar, mahasiswa dsb.); 5) grup-grup kepentingan atau interest groups (organisasi buruh, nelayan, tani, veteran, pensiunan, organisasi-organisasi profesional lainnya dan serbagainya.); 6) gerakan-gerakan atau movements atau sering juga disebut grup penekan atau pressure groups (organisasi lingkungan hidup, perlindungan konsumen, bantuan hukum non profit); 7) pembangunan (lembaga swadaya masyarakat, perbaikan gizi dan kesehatan, keluarga berencana dsb.); 8) organisasi kemasyarakatan lainnya (pengamat pemilu, pengamat DPR, pengamat korupsi, forum diskusi dan pengkajian dan sebagainya).

Pembidangan dari civil society di atas tidak perlu ketat, bidang ekonomi sering juga mempunyai misi di bidang pembangunan, bergerak sebagai pressure groups dan sebagainya. Bahkan organisasi-organisasi yang masuk civil society ini tidak jarang berbicara mengenai politik dan pemerintahan dan mempengaruhi sistem politik dan keputusan politik atau kebijaksanaan pejabat pemerintah agar kebijaksanaan itu tidak merugikan organisasi dan anggotanya. Ini dibenarkan dan membuat demokrasi itu hidup dan menjadi budaya politik masyarakat yang penting. Bedanya dengan partai politik ialah bahwa civil society tidak turut serta ambil bagian atas nama organisasinya dalam pemilu sedang partai politik ambil bagian dalam pemilu atas nama partainya itu. Biasanya civil society memberi kebebasan kepada para anggotanya untuk memilih partai (dalam sistem proporsional) atau orang yang dicalonkan partai (sistem distrik) dalam pemilu untuk duduk sebagai wakilnya di lembaga perwakilan dan eksekutif, walaupun tidak jarang pengurus civil society memberi arahan pada para anggotanya untuk memilih partai atau orang tertentu dalam suatu pemilu. Hubungan civil society dengan pemerintahan dan demokrasi, dapat dijelaskan sebagai berikut ini: ${ }^{2}$

"Dalam demokrasi, pemerintah hanyalah salah satu unsur yang hidup berdampingan dalam suatu struktur sosial dari lembaga-lembaga yang banyak dan bervariasi, partai politik, organisasi dan assosiasi. Keanekaragaman ini disebut 5-6.

"Larry Diamond. "Toward Democratic Consolidation." Jumal of Democracy Vol. 5 No. 3 July 1994. Him.

2United States Information Agency. Apakah Demokrasi Itu?. Publikasi Oktober 1991. Hlm. 5-6. 
pluralisme, dan ini berasumsi bahwa banyak kelompok terorganisasi dan lembaga dalam suatu masyarakat demokratis tidak tergantung pada pemerintah bagi kehidupan, legitimasi atau kekuasaan mereka. Ribuan organisasi swasta bekerja dalam masyarakat demokratis, ada yang lokal, ada yang nasional. Banyak diantaranya berperan sebagai penghubung antara individu dan lembaga-lembaga sosial dan pemerintah yang rumit dimana mereka merupakan bagiannya, mengisi peran yang tidak diberikan kepada pemerintah dan menawarkan kesempatan kepada individu untuk menjalankan hak dan tangungjawab mereka sebagi warga negara demokrasi. Kelompok-kelompok itu mewakili kepentingan anggota mereka dalam berbagai cara dengan mendukung calon bagi jabatan pemerintah, memperdebatkan isu-isu dan berusaha mempengaruhi keputusn politik. Melalui kelompok demikian orang mempunyai salurn untuk berpartisipasi secara bermakna baik di pemerintahan maupun di masyarakat mereka sendiri."

Di indonesia, uraian mengenai civil society di atas belum sepenuhnya dapat diterapkan tetapi sudah menuju ke arah sana akibat derasnya ans reformasi yang telah menurunkan pemerintahan Orde Baru dan Kabinet Reformasi Pembangunan serta menghasilkan pemerintahan yang kuat legitimasinya berdasarkan pemilihan umum. Dalam ketentuan yang masih berlaku sekarang semua organisasi yang disebutkan di atas disebut sebagai organisasi kemasyarakatan sebagaimana diatur dalam Pasal 1 UU No. 8 tahun 1985 dengan rumusan:
“Organisasi kemasyarakatan adalah organisasi yang dibentuk oleh anggota masyarakat Warga negara Republik Indonesia secara sukarela atas dasar kesamaan kegiatan, profesi, fungsi,agama dan kepercayaan terhadap Tuhan Yang Maha Esa, untuk berperanserta dalam pembangunan dalam rangka mencapai tujuan nasional dalam wadah Negara Kesatuan Republik Indonesia yang berdasarkan Pancasila."

Menurut undang-undang ini organisasi kemasyarakatan ini "dibina" oleh pemerintah, dan dapat "dibekukan dan dibubarkan" oleh pemerintah apabila a.l. melakukan kegiatan yang mengganggu keamanan dan ketertiban umum; dan organisasi kemasyarakatan ini berhimpun dalam suatu wadah pembinaan dan pengembangan yang sejenis. Dengan tekad pemerintah yang legitimege untuk menegakkan hukum dan demokrasi maka organisasi kemasyarakatan menurut UU No. 8 Tahun 1985 secara perlahan akan bergeser menuju civil society.1) Pada bidang-bidang pemerintahan dan pembangunan mana saja civil society dapat berpartisipasi? 2) Bagaimana civil society memposisikan dirinya agar dapat berpartisipasi secara maksimal dalam pemerintahan dan pembangunan?

\section{Civil Sociaty dan Otonomi Daerah}

UU No. 22. Tahun 1999 tentang Pemerintahan daerah sebagai pengganti UU No. 5 Tahun 1974 yang sangat sentralistis itu, melalui arahan dan ketentuan dalam pasalpasalnya membuka atau memberi kesempatan kepada masyarakat daerah masing-masing untuk turut atau berinisitif aktif berpartisipasi 
dalam pemerintahan dan pembangunan didaerahnya. Tidak kurang dua rumusan arahan dan 14 pasal melalui ayat atau butir pasal atau ayatnya yang mengatur kesempatan atau keharusan masyarakat daerah berpartisipasi dalam pemerintahan dan pembangunan didaerahnya dalam UU No. 22 Tahun 1999. Arahan dimaksud dimuat dalam "PERTIMBANGAN" undang-undang tersebut dengan rumusan:

butir b : bahwa dalam penyelenggaraan Otonomi Daerah, dipandang perlu untuk lebih menekankan pada prinsip-prinsip demokrasi, peran serta masyarakat, pemerataan dan keadilan, serta memperhatikan potensi dan keanekaragaman Daerah;

butir C : bahwa dalam menghaadapi perkembangan keadaan, baik di dalam maupun di luar negeri, serta tantangan persaingan global, dipandang perlu menyelenggarakan Otonomi Daerah dengan memberikan kewenangan yang luas, nyata dan bertanggung jawab kepada daerah secara proporsional, yang diwujudkan dengan peraturan, pembagian keuangan Pusat dan Daerah, sesuaidengan prinsip-prinsip demokrasi, peran serta masyarakat, pemerataan dan keadilan, serta potensi dan keanekaragaaman daerah, yang dilaksanakan dalam kerangka Negara Kesatuan Republik Indonesia.

Pasal-pasal yang memberikan kesempatan untuk berpartisipasi bagi masyarakat daerah, setidaknya diatur dalam:
Pasal 11 ayat (2): yaitu bidang pemerintahan wajib dilaksanakan Daerah Kabupaten dan kota meliputi: pekerjaan umum, kesehatan, pendidikan dan kebudayaan, pertanian, perhubungan, industri dan perdagangan, penanaman modal, lingkungaan hidup, pertanahan, koperasi dan tenaga kerja.

Pasal 18 ayat (1) h: DPRD mempunyai tugas dan wewenang menampung dan menindaklanjuti aspirasi daerah dan masyarakat;

Pasal 22 butir $\mathrm{c}, \mathrm{d}$ dan e: DPRD mempunyai kewajiban membina demokrasi dalam penyelenggaraan Pemerintahan Daerah; meningkatkan kesejahteraan rakyat di daerah berdasarkan demokrasi ekonomi, dan memperhatikan dan menyalurkan aspiraasi, menerima keluhan dan pengaduan masyarakat, serta memfasilitasi tindk lanjut penyelesaiannya;

Pasal 33 butirj: Yang dapat ditetapkan menjadi Kepala Daerah (bellaku juga bagi Wakil Kepala Daerah) adalah warga negara Republik Indonesia dengan syarat: mengenal daerahnya dan dikenal oleh masyarakat di daerahnya;

Pasal 43 butir $c_{\text {, e dan f: Kepala Daerah }}$ mempunyai kewajiban menghormati kedaulatan rakyat, meningkatkan taraf kesejahteraan rakyat dan memelihara ketentraman dan ketertiban masyarakat;

Pasal 48 butir $b$ : Kepala Daerah dilarang membuat keputusan yang secara khusus memberikan keuntungan 
bagi dirinya, anggota keluarganya, kroninya, golongan tertentu, atau kelompok politiknya yang secara nyata merugikan kepentingan umum atau mendiskriminasikan warga negara dan golongan masyarakat;

Pasal 49 butir $\mathrm{g}$ : Kepala Daerah berhenti atau diberhentikan karena mengalami krisis kepercayaan publik yang luas akibat kasus yang melibatkan tanggung jawabnya, dan keterangannya atau kasus itu ditolak oleh DPRD;

Pasal 76: Daerah mempunyai kewenangan untuk melakukan pengangkatan, pemindahan, pemberhentian, penetapan pensiun, gaji, tunjangan dan kesejahteraan pegawai, serta pendidikan dan pelatihan sesuai dengan kebutuhan dan kemmpuan Daerah yang ditetapkan dengan Peraturn Daerah berdasarkan peraturan perundang-undangan yang berlaku;

Pasal 87 ayat (3): Daerah dapat mengaadakan kerjasama dengan badn lain yang diatur dengan keputusan bersama;

Pasal 92 ayat (1) dan ayat (2): Dalam penyelenggaraan pembangunan Kawasan Perkotaan, Pemerintahan Daerah perlu mengikutsertakan masyarakat dan pihak swasta, pengikutsertaan masyarakat merupakan upaya pemberdayaan masyarakat dalam pembangunan perkotaan;

Pasal 93 ayat (1) : Desa dibentuk, dihapus dan/atau digabung dengan memperhatikan asal usulnya atas prakarsa masyarakat dengan persetujuan Pemerintahan Kabupaten dan DPRD;

Pasal 111: Peraturan Daerah yang mengatur lebih lanjut mengenai Desa wajib mengakui dan menghormati hak, asal usul dạn adatistiadat Desa.

Arahan dan pasal-pasal yang disebutkan di atas diperjelas kembali melalui Penjelasan Umum dan Pasal demi pasal dari UU No. 22 tahun 1999. Tetapi ada satu hal yang perlu dikemukakan tentang pernyataan dalam Penjelasan Umum yang perlu dicermati masyarakat di daerah yaitu yang dikemukakan dalam Penjelasan Umum 1 butir e dengan rumusan:

"Hal-hal yang mendasar dalam undangundang ini adalah mendorong untuk memberdayakan masyarakat, menumbuhkan prakarsa, meningkatkan peran serta masyarakat, mengembangkan peran dan fungsi Dewan Perwakilan Rakyat Daerah".

Begitu besar keinginan UU No. 22 Tahun 1999 mendorong partisipasi masyarakat daerah dalam pemerintahan dan pembangunan seperti diuraikan di atas, agar perencanaan pembangunan sebagian besar inisiatifnya berasal dari masyarakat daerah (bottom up). Untuk dapat berpartisipasi seperti itu peranan civil society daerah bersangkutan sangat diperlukan terutama dalam memotivasi dan mengartikulasikn kepentingan masyarakat daerahnya.

Semua civil society yang adá di daerah tersebut harus bersama-sama memperjuangkan kepentingan daerahnya, bukan hanya kepentingan civil society-nya saja, mereka 
harus duduk bersama dan berdialog atau berdiskusi bahkan dengan perorangan (tokoh non formal) agar diperhitungkan oleh pemerintah dan kekuatan politik yang ada di daerah tersebut. Civil society ini harus kuat legitimasinya dari masyarakat daerahnya, misi dn visinya jelas, dan tingkah laku para pengurusnya di pusat maupun di daerah sampai ke pedesaan harus dapat dijadikaan teladan masyarakat. Yang jelas civil society tersebut yang akan berpartisipasi dalam perundingan, diskusi dalam perencanaan pembangunan dan dalam penentuan orangorangnya dalam suatu sistem politik, harus mempunyai kekuatan dan kemampuan sesuai bidang-bidang tadi, kalau tidak maka hanya jadi penonton yang baik atau penonton yang frustasi dalam pemerintahan dan pembangunan.

Setiap civil society daerah harus mempunyai kemampuan dan kekuatan "plus" baik dari segi organisasi, kepengurusan, misi dan visinya dan terutama penguasaannya dalam mengakses dan mengolah informasi lokal, regional, nasional dan internasional, karena siapa menguasai informasi, maka umumnya menguasai percaturan dan isu-isu bidang-bidang yang ditekuninya. Dengan kemampuan dan ketentuan seperti itu setiap civil society mampu membaca, mengkaji peluang yang diberikan UU No. 22 Tahun 1999 kepada masyarakat, memilih dan merencanakan bidang-bidang mana yang ditekuni atau diambilnya sebgai partisipasinya dalam pembangunan daerahnya. Kemudian memperjuangkannya untuk dijadikan keputusan pemerintah daerah atau keputusan politik lainnya, agar semuanya menguntungkan daerahnya yang pada gilirannya juga masyarakat Indonesia secara keseluruhan. Dengan demikian civil society menjadi salah satu unsur penting dan berpengaruh dalam sistem politik di daerahnya, tanpa ikut serta dalam partai politik. Dapat menjadi unsur penting dalam sistem politik berarti diakui mempunyai kompetensi "mengartikulasikan" kepentingan anggota masyarakat daerahnya bahkan tidak berlebihan bila diakui berkompetisi "mengaregasikan" artikulasi kepentingan tadi untuk dijadikan sebagai alternatif kebijaksanaan pemerintah daerah. Artikulasi kepentingan adalah: ${ }^{3}$

- merupakan cara yang lazim ditempuh oleh anggota masyarakat agar kepentingan, kebutuhan atau tuntutannya dapat terpenuhi dengan memuaskan. Berbagai macam kepentingan itu dapat terpenuhi oleh sistem politik bilamana dikemukakan secara nyata, baik melałui organisasi maupun lembaga-lembaga yang ada dalam masyarakat. Agregasi kepentingan merupakan suatu fungsi input yang memadukan semua kepentingan yang telah diartikulasikan.

Suatu civil society bila mampu mengartikulasikan kepentingan masyarakat bahkan lebih dari itu mampu merubahnya menjadi agregasi kepentingan maka civil society tersebut dapat disebutkan punya

${ }^{3}$ Gabriel AAlmod. 1978. Comparative Politic System, Process, and Policy. Boston: Little Brown and Company. 
"pengaruh"4 adalah bentuk lunak dari kekuasaan, yang kuat di daerahnya. Menurut Nagels pengaruh adalah:

"hubungan antara pelaku-pelaku demikian yang menginginkan, menghendaki, lebih menyukai atau bermaksud agar satu atau lebih pelaku mempengaruhi perbuatan atau mudah terpengaruh untuk berbuat, satu atau lebih pelaku lain."

Menjadi salah satu unsur berpengaruh dalam lingkungan sistem politik di daerah maka pemerintah daerah, lembaga-lembaga politik di daerah memerlukan dukungan dari civil society tersebut dalam penyelenggaraan pemerintahan dan mensukseskan programprogram mereka. Kalau yang demikian itu dapat terjadi maka civil society akan lebih mudah menggoalkan tuntutan-tuntutannya (artikulasi kepentingan dan agregasi kepentingan yang biasanya dalam bentuk aternatif-alternatif) untuk dijadikan kebijaksanaan pemerintah daerah, DPRD dan partai-partai politik-politik di daerahnya.
Proses kepentingan masyrakat menjadi kebijaksanaan daerah sangat diharapkan oleh' UU No. 22 tahun 1999 dan ini jugalah yang disebut perencanaan dan pelaksanaañ pembangunan yang bottom up. Secara luas ${ }^{6}$ memberikan gambaran diagramatis bertungsinya sebuah sistem politik menunjukkan apa yang terjadi daläm pengaruh-pengaruh lingkungan sistem politik tersebut melalui bermacam-macam pengaruh yang mengalir menuju sistem tersebut. Melalui struktur dan prosesnya sistem tersebut kemudian bertindak berdasarkan apa yang terjadi dengan cara sedemikian rupa yang kemudian diubah menjadi out put (kebijakšanaan).

Sengaja disajikan arahan dan pasal-pasal dari UU No. 22 Tahun 1999 agar civil society dapat melihat dan mengkaji partisipasi apa yang biasa dikembangkan untuk kemakmuran warga dan daerahnya. Terserah pada masingmasing civil society menilai dirinya dengan memperhitungkan kekuatan, kelemahan, kesempatan dan hambatan-hambatan internal dan eksternalnya sehingga dapat

Meminjam diagram David Easton:

Lingkungan

1. Civil society

2. Pemimpin non formal $n$

3. Dari luar daerah

4. DLL

lingkungan

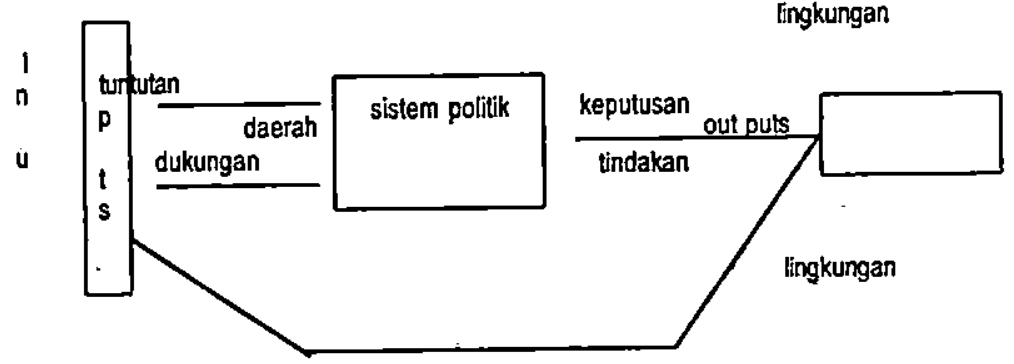

Miriam Budiardjo. 1994. Demokrasi di Indonesia. Jakarta: Gramedia Pustaka Utama. Hlm. 36.

${ }^{5}$ Robert A. Dahl. 1985. Analisa Politik Modem. Jakarta: Bumi Aksara. Him. 38.

BDavid Easton. 1984. Kerangka Kerja Analisa Sistem Politik. Publikasi Oktober 1991. 
tetap memilih bidang yang akan ditekuninya dalam pembangunan daerah. satu hal yang pasti dan menarik dari UU No. 22 tahun 1999 ialah rumusan pasal 11 nya yang menetapkan 11 bidang yang wajib dilaksanakan oleh Daerah Kabupaten dan daerah kota dalam rangka otonomi daerah yaitu meliputi: 1) pekerjaan umum, 2) kesehatan, 3) pendidikan dan kebudayaan, 4) pertanian, 5) perhubungan, 6) industri dan perdagangan, 7) penanaman modal, 8) lingkungan hidup, 9) pertanahan, 10) koperasi dan 11) tenaga kerja. Di samping itu masih terbuka peluang di bidang lain apabila dicermati dengan baik, seperti untuk pencalonan Kepala Daerah dan wakilnya, penentuan calon-calon wakil rakyat di DPR, DPRD dan MPR dan juga di bidang pengawasan.

Harus diakui juga bahwa untuk dapat berpartisipasi maksimal dalam pembangunan daerah tidak hanya tergantung dari diri (internal) civil society. Walaupun civil society sudah solid secara organisasi, punya SDM yang baik dan punya pengurus yang berwibawa masih membutuhkan dukungan faktor eksternal agar dapat berpartisipasi maksimal dalam pemerintahan dan pembangunan. Faktor eksternal dimaksud adalah dukungan pemerintah daerah dan partisipasi masyarakat daerah dan simpatisannya dalam menyampaikan ide atau gagasan, kebutuhannya, kepentingannya dan kritiknya kepada civil society bersangkutan.

\section{Faktor Pemerintah Daerah}

Agar UU No. 22 Tahun 1999 dapat dilaksanakan di daerah dengan baik dan masyarakat berperan serta dalam pemerintahan dan pembangunan maka pemerintah daerah yang selama ini bekerja berdasarkan UU No. 5 Tahun 1974 yang sentralistis itu harus berubah (terutama para pejabatnya) dan menyesuaikannya dengan keinginan undang-undang baru itu, atau dengan istilah populer sekarang ini, harus mengalami reposisi dan restrukturisasi. Sesuai ketentuan undang-undang baru ini DPRD bukan lagi bagian dari Pemerintah Daerah tetapi sebagai Badan Legislatif Daerah, berkedudukan sejajar dan menjadi mitra dari Pemerintah Daerah; sedang Pemerintah Daerah adalah Badan Eksekutif Daerah yang terdiri dari Kepala daerah beserta perangkat daerah lainnya. Dengan wewenang yang bertambah besar diberikan kepada DPRD terutama dalam memilih dan menetapkan Kepala Daerah Kabupaten dan Kota, meminta pertanggungjawabannya dan mengusulkan pemberhentiannya apabila pertanggungjawabannya ditolak DPRD sampai dua kali; dan mengingat kewenangan yang begitu luas diberikan kepada daerah terutama melalui Pasal 7 dan 11 UU No. 22 Tahun 1999, yaitu:

\section{"mencakup kewenangan dalam} seluruh bidang pemerintahan kecuali kewenangan dalam bidang politik luar negeri, pertahanan keamanan, perdilan, moneter dan fiskal, agama serta kewenangan bidang lain;

Bidang pemerintahan yang wajib dilaksankan Daerah Kabupaten dan Kota meliputi: pekerjaan umum, kesehatan, pendidikan dan kebudayaan, pertanian, perhubungan, industri dan perdagangan, penanaman modal, lingkungan hidup, pertanahan, koperasi dan tenaga kerja." 
Pemerintah daerah-lah yang terutama mengalami restrukturisasi. Kemudian agar prinsip-prinsip penyelenggaraan otonomi derah dapat terlaksana yaitu demokrasi, peran serta masyarakat, pemerataan dan keadilan; dan hal-hal yang mendasar dalam UU No. 22 Tahun 1999 juga terwujud yaitu memberdayakan masyarakat, menumbuhkan prkrsa dan kreativitas, meningkatkan peran serta masyarakat, maka pegawai negeri sipil terutama yang diberi kesempatan menjadi birokrat harus mengalami reposisi. Mereka harus netral dari kekuatan politik, dan ini sesuai dengan ketentuan Pasal 3 PP No. 12 Tahun 1999 yang menyatakan bahwa pegawai negeri sipil harus bersikap netral dan menghindari penggunaan fasilitas negara untuk golongan tertentu, dan dalam Pasal 7 disebutkan bahwa pegawai negeri sipil yang menjadi anggota dan atau pengurus partai politik, maka keanggotaan dan atau kepengurusan yang bersangkutan hapus secara otomatis, kecuali mereka yang tetap ingin di parpol dan harus menerima konsekuensinya yaitu diberhentikan dari jabatan negeri.

Dalam melakukan restrukturisasi dan reposisi dimaksud, perlu diperhatikan dan bila mungkin dijadikan pedoman konsep ilmiah yang sangat populer dewasa ini yaitu konsep good govemance dan reinventing government. Secara umum dapat dikatakan bahwa indikator-indikator untuk dapat disebut sebagai good governance adalah:? a) melaksanakan Hak Asasi Manusia; b) masyarakat berpartisipasi dalam pengambilan keputusan politik; c) melaksanakan hukum untuk melindungi kepentingan masyarakat; d) mengembangkan ekonomi pasar atas dasar tanggung jawab kepada masyarakat; e) orientasi politik pemerintah menuju pembangunan.

Penyelenggaraan pemerintahan yang kurang baik (bad governance) diidentifikasikan dengan indikator-indiktor: 1) hal-hal yang bersifat publik dn pribadi, baik dalam tatalaksana maupun kepemilikannya tidak jelas perbedaannya; 2) terlalu banyak regulasi pada birokrasi, sehingga menghalngi berfungsinya mekanisme pasar; 3 ) berbagai peraturan yang berlaku tidak mendukung terciptanya iklim kondusif dalam mendorong pembangunan; 4) perhatian pada HAM kurang; 5) prioritas tidak sesuai dengan kebutuhan pembangunan; 6) pengambilan keputusn tidak transpran dan kurangnya partisipasi masyarakat.

Reinventing govemmen $\beta$ memperkenalkan paradigma baru pemerintah di pusat atau daerah yaitu pemerintah yang mampu memposisikan diri dan berperan sebagai berikut:

a) Catalytic Govemment (pemerintah yang katalitik). Pada kedudukan seperti ini pemerintah menempatkan diri sebagai katalisator bagi aktivitas masyarakat dan lebih berperan sebagai pengemudi ketimbang sebagai pendayung.

${ }^{7}$ Robert Hass. The Issue of Govemance in Intemational Cooperation. Berlin Agustus 1997.

Bavid Osborne \& Ted Gpebler. 1992. Reinventing Government. Addision Wesley. New York: Pub. Com. Inc. HIm. 4 
b) Community - owned Goverment (pemerintah yang dimiliki rakyat). Pemerintah menciptakan kondisi di mana masyarakat merasa bahwa pemerintah yang ada itu adalah milik mereka. Di sini pemerintah lebih memberi kewenangan kepada masyarakat daripada memberikan pelayanan. Hal tersebut didasarkan pada asumsi bahwa masyarakat lebih memahami masalah-masalah yang mereka hadapi daripada orang lain.

c) Competitive Government (pemerintah yang kompetitif). Pada kedudukan seperti ini pemerintah menyuntikkan persaingan dalam penyelenggaraan jasa dengan pihak swasta. Jadi bukan hanya swasta yang bisa efisien, pemerintah juga bisa efisien.

d) Mission - Driven Govemment (pemerintah yang dikendalikan oleh misi). Kegiatan pemerintah didasarkan pada misi yaitu apa yang ingin dicapai, bukan pada aturan yang melandasi kegiatannya. Bila kita terperangkp pada aturan bisa jadi tujuan yang akan dicapai malahan tidak tercapai, karena peraturan sering kali terlambat menyesuaikan diri dengan perubahan yang cepat terjadi.

e) Result - Oriented Govemment (pemerintah yang berorientasi pada hasil). Pemerintah lebih mengutamakan mengeluarkan dana untuk hasil yang ingin dicapai (outputs)bukan mengutamakan pembiayaan pada masukan-masukan (inputs).

f) Customer-Driven Govemment (pemerintah yang berorientasi pada pelanggan). Pemerintah seperti ini mengutamakan kebutuhan pelanggan yaitu masyarakat, bukan kebutuhan birokrasi. Sering terjadi bahwa masyarakat yang tidak memperoleh perlakuan yang baik dari pemerintah mereka akan cenderung memanfaatkan jasa swasta. Karena itu pemerintah sekarang harus lebih banyak mendengrkn aspirasi pelanggan dengan berbagai metode yang modern dan lebih akurat.

g) Enterprising Government.(pemerintah yang dikelola dengan semangat wiraswasta). Karakteristik pemerintah yang bersemangat wiraswasta ialah memandang pengeluaran dalam prespektif investasi, artinya uang akan didapat apabila melakukan investasi.

h) Anticipatory Government (pemerintah yang antisipatif). Pemerintah seperti ini adalah yang berorientasi mengantisipasi masalah dan menangkap peluang masa depan ketimbang lebih asyik menangani krisis demi krisis.

i) Decentralized Government (pemerintah yang terdesentralisasi). Pemerintah seperti ini adalah yang dapat melonggarkan hubungan hierarkis lewat pelimpahan kewenangan kepada organisasi yang lebih rendah untuk mengambil keputusan dan dalam tiap organisasi publik diterapkan manajemen partisipatif.

j) Market -oriented Government (pemerintah yang berorientasi kepada pasar). Pemerintah seperti ini adalah yang mampu mengemudikan dan membuat struktur pasar untuk menciptakan insentif yang menyebabkan orang bergerak ke arah yang dikehendaki oleh monuniti dan membiarkan mereka mengambil keputusan sendiri. Bila pemerintah dapat menciptakan insentif yang mempengaruhi keputusan pasar, berarti dapat melipatgandakan dampaknya sampai beratus kali lipat. 
Pemerintah daerah yang dapat menyesuaikan diri atau mengarah pada good governance dan menerima paradigma baru melalui reinventing government akan memudahkan daerah tersebut memasuki AFTA, APEC dan mengundang investasi luar negeri di samping yang telah disebut pada bagian atas yaitu mendorong untuk memberdayakan masyarakat, menumbuhkan prakarsa dan kreativitas, meningkatkan peran serta masyarakat dan memberi peluang bagi prinsip demokrasi, pemerataan dan keadilan serta memperhatikan potensi dan keanekargaman Daerah. UU No. 22 Tahun 1999 dengan jelas juga menyatakan bahwa derah dapat mengadakan kerjasama yang saling menguntungkari deñgan lembaga/ badan di lur negeri, sehingga kedua konsep di atas sangat mendukung ketentuan tersebut. Dukungn pemerintah daerah saja belum cukup, masih perlu dukungan dari faktor eksternal lainnya yaitu masyarakat daerah.

\section{Faktor Masyarakat}

Dapat dikatakan bahwa masyarakat di daerah sekarang ini masih kuat tradisi yang kurang menunjang pembangunan, tetapi tradisional bukan berarti tidak dinamis dan tidak mau mengalami perubahan melainkan karena sikap mental anggota masyaräkatnya yang umumnya masih lambat berubah. Itu bukan berarti masyarakat kita tidak mengalami kemajuan, tetapi belum sebagaimana diharapkan. Sikap mental kita harus berubah dari yang selama ini kita anut (tradisi) ke sikap mental yang modern tetapi bukan westernisasi, kita harus menerima modernisasi.? Kita harus berani mengubah sikap mental kita ke arah yang lebih baik untuk kemajuan masyarakat kita ke depan ini yang banyak tantangan dan peluang bagi kita.

Masalah sikap mental ini kami sependapat dengan gagasan yang mengatakan:10

Sikap mental adalah suatu istilah populer untuk dua konsep yang dengan istilah ilmiah disebut "sistem nilai budaya" (Culture value system) dan "sikap" (attitude): Sistem nilai budaya adalah suatu rangkaian dari konsep abstrak yang hidup dalam alam pikiran sebagian besar dari warga suatu masyarakat, mengenai apa yang harus dianggap penting dan berharga dalam hidupnya. Dengan demikian suatu sistem nilai budaya itu biasanya merupakan bagian dari kebudayaan yang berfungsi sebagai pengarah dan pendorong kelakuan manusia. Karena sistem nilai budaya itu hanya merupakan konsepkonsep yang abstrak, tanpa perumusan yang tegas, maka konsep-konsep itu biasanya hanya bisa dirasakan tetapi sering tidak dapat dinyatakan dengan tegas oleh warga masyarakat yang bersangkutan ... maka sering amat mendarah daging pada mereka dan sukar dirobah atau diganti dengan konsepkonsep baru. Sikap bukan merupakan

9J. W. Schoorl. 1980. Moderenisasi. Jakarta: Gramedia. HIm. 20.

${ }^{10 K o e n t j o r o n i n g r a t . ~ 1979 . ~ M a n u s i a ~ d a n ~ K e b u d a y a a n ~ d i ~ I n d o n e s i a . ~ J a k a r t a: ~ J a m b a t a n . ~ H I m . ~ 380-381 . ~}$ 
bagian dari kebudayaan, tetapi merupakan suatu hal kepunyaan para individu warga masyarakat. Suatu sikap adalah potensi pendorong yang ada dalam jiwa individu untuk bereaksi terhadap lingkungannya beserta segala hal yang ada di dalam lingkungannya itu, dalam hal ini berupa manusia lain, binatang, tumbuh-tumbuhan, benda atau konsep-konsep. Sikap individu itu biasanya ditentukan oleh tiga unsur, ialah kegiatan fisik dari individu, keadaan jiwanya dan norma-norma serta konsepkonsep nilai budaya yang dianutnya.

Dengan konsep di atas maka kita tentunya akan sependapat bahwa sikap mental masyarakat kita harus mengalami perubahan ke arah yang lebih baik kalau tidak, mungkin akan menjadi penonton yang frustasi dalam pemerintahan dan pembangunan terutama di daerah.

Kita tidak hanya bisa mengatakan bahwa sikap mental kita belum cukup baik untuk berpartisipasi dalam pembangunan, tetapi kita harus memberi arahan juga bagaimana sebaiknya mental bangsa Indonesia agar bisa berpartisipasi optimal dalam pembangunan tersebút. Ada 5 (lima) konsep sistem nilai budaya" yang cocok untuk pembangunan, yaitu:

1. Dalam menghadapi hidup, orang harus menilai tinggi unsur-unsur yang menggembirakan dari hidup; dan bahwa ada kesengsaraan, bencana, dosa dan keburukan dalm hidup memang harus disadari dan hal itu semuanya adalah untuk diperbaiki. Sikap yang aktif yang harus dinilai tinggi sebagai pengarah tindakan utama bukan sikap yang pasif dan fatalistis. Jangan mengingkari hidup dan melarikan diri kepad kebtiln atau hal-hal yang trasendental.

2. Harus menilai tinggi konsepsi bahwa orang mengintensifkan karyanya untuk menghasilkan lebih banyak karya lagi. Aktivits jangan hanya ditujukan kepada usaha untuk mencari makan memenuhi kebutuhan primer, dan mendambakan pekerjaan sebagai pegawai yang duduk di belakang meja saja. Mentalitas pegawai yang hanya mementingkan karya untuk naik pangkat dan kedudukan harus dibuang jauh-jauh. Demikian juga kegiatan untuk mencari gelar-gelar akademis tanpa mementingkan ketrampilan keahlian yang ada dibelakangnya harus juga disingkirkan. Sikap mental seperti itu terang meremehkan kwalitas, karya serta hasilnya tidak mendorong orang untuk tabah dan ulet.

3. Harus merasakan keinginan untuk dapat menguasai alam serta kaidah-kaidahnya. Keinginan untuk menguasai alam dan kaidah-kaidahnya itu adalah sumber dari ilmu pengetahuan. Pembangunan ekonomi yang modem dalam tahap lebih lanjut yaitu industrialisasi hanya bisa dicapai dengan ilmu pengetahuan dan teknologi. Kalau kita terus mengimpor ilmu pengetahuan dan teknologi kita hanya menjadi bangsa kelas dua yang terus menjadi konsumen teknologi negaranegara maju.

"1/bid. Hlm. 382-385. 
4. Dalam segala aktivitas hidup, orang harus sebanyak mungkin berorientasi ke masa depan. Suatu organisasi ke masa depan sangat perlu, karena sikap mental seperti itu merupakan pangkal dari keinginan untuk menabung dan juga mendorong orang untuk merencanakan hidupnya setajam mungkin ke masa yang akan datang. Sifat yang sering mengenang dan merindukan masa lalu yang jaya dan enak bagi sementara masyarakat kita akan mudah mengarahkan kita ke arah kekecewaan bahkan mungkin frustasi.

5. Dalam menghadapi keputusankeputusan orang harus bisa berorientasi kesesamanya, menilai tinggi kerjasama dengan orang lain, tanpa meremehkan kwalitas individu dan tanpa menghindari tanggung jawab sendiri. Konsep kelima ini mengajarkan kita agar jangan terlalu berorientasi ke atas. Mentalitet berorientsi $k e$ atas membuat orang segan untuk memutuskan sesuatu yang belum pernah dialami, dan harus menunggu contoh dan restu dari orang-orang yang lebih tua atau lebih tinggi pangkat dan kedudukannya. Mentalitet seperti ini membuat orang bermental pegawai dan kurang berani berdiri sendiri dan bertanggung jawab.

Perubahan sikap mental masyarakat ke arah yang disebutkan di atas akan mendorong partisipasi masyarakat dalam pemerintahan dan pembangunan secara optimal.

Masyarakat (daerah) akan lebih mudah mendukung civil society apabila memiliki sikap mental seperti yang dikemukakan di atas. Masalahnya, membawa masyarakat derah lebih maju di samping membutuhkan waktu, juga dana dan daya. UU No. 22 Tahun 1999 telah mengarah untuk memberdayakan masyarakat, menumbuhkan prakarsa dan kreativitas masyarakat dan meningkatkan peranserta masyarakat, tinggal bagaimana menggerakkan masyarakat agar berada pada posissi seperti itu. Pemerintah dan civil society akan berperanan besar untuk itu, dan apabila civil society dapat menjadi salah satu agen utama dalam perubahan daerah ke masyarakat modern, maka masyarakat kita itu akan memberikan dukungan pada civil society dalam melaksanakan visi dan misinya. Itu berarti juga civil society dapat mengklim atau memposisikan dirinya sebagai salah satu organisasi yang berhak mengartikulasikan kepentingan atau tuntutan masyarakat daerahnya bahkan kalau mungkin mengagregasikan kepentingan dan tuntutan tersebut menjadi salah satu alternatif untuk dijadikan output oleh pemerintah daerah/ nasional dan badan-badan atau institusi lainnya.

\section{Simpulan}

Sebagai penutup dari tulisan ini, maka dapat dikemukakan hal-hal sebagai berikut:

1. UU No. 22 Tahun 1999 tentang Pemerintahan Daerah telah memberi kesempatan kepada masyarakat Daerah untuk berpartisipasi dan berprakarsa dalam pemerintahan dan pembangunan melalui pertimbangan pasal-pasalnya dan penjelasan umumnya.

2. Agar partisipasi dan prakarsa masyarakat tersebut dapat tumbuh dan terpeliharaa berkembang dan tersalurkan, dibutuhkan kehadiran civil society di daerah tersebut untuk mengartikulasikannya. 
3. Agar dapat mengartikulasikan kebutuhan dan tuntutan masyarakat daerah maka civil society tersebut harus solid dalam arti benar-benar memenuhi kriteria sebagai civil society serta mendapat dukungan dari pemerintah daerah dan masyarakat daerah itu sendiri. $\square$

\section{Daftar Pustaka}

Almod, Gabriel A. 1978. Comparative Politics System Process and Policy. Boston: Little. Brown and Company.

Budiardjo, Miriam. 1994. Demokrasi di Indonesia. Jakarta: Gramedia Pustaka Utama.

Clark, Robert P. 1989. Menguak Kekuasaan dan Politik di Dunia Ketiga. Jakarta: Erlangga.

Dahl, Robert A. 1985. Analisa Politik Modern. Jakarta: Bumi Aksara.

Diamond, Larry. "Toward Democratic Consolidation." Jurnal of Democracy Vol. 5 No. 3 July 1994
Dove, Michael R. 1985. Peranan Kebudayaan Tradisional Indonesia dalam Modernisasi. Yogyakarta: Yayasan Obor Indonesia.

Easton, David. 1984. Kerangka Kerja Analisa Sistem Politik. Jakarta: Bina Aksara.

Hass, Robert. The Issue of Good Govemance in International Cooperation. Berlin. Agustus 1997.

Koentjaraningrat. 1979. Manusia dan Kebudayaan di Indonesia. Jakarta: Jambatan.

Osborne, David \& Ted Goebler. 1992. Reinventing Government, Addision Wesley. New York: Pub. Comp.Inc.

Schoorl, J.W. 1980. Modernisasi, Jakarta: Gramedia.

United States Information Agency. Apakah Demokrasi itu. Publikasi. Oktober 1991. 